\title{
Experiments on Extinction of Liquid Hydrocarbon Fires by a Foam Technique
}

\author{
T. P. SHARMA, R. S. CHIMOTE, S. B. GUPTA and JAGBIR SINGH \\ Fire Research Laboratory \\ Central Building Research Institute, \\ Roorkee-247667(U.P.), India
}

\begin{abstract}
A series of experiments on gasoline, kerosene and diesel oil fires were conducted in a $1 \mathrm{~m}$ high open-top mild steel tank of size : $4.0 \mathrm{~m} \times 2.5 \mathrm{~m}$ in order to study how efficiently the liquid hydrocarbon fires in flammable liquid storage tanks could be extinguished by a direct foam injection technique(DFIT) into the combustion zone of fire. For $10 \mathrm{~m}^{2}$ size gasoline, kerosene and diesel oil fires, the direct foam injection technique, using indigeneously available protein foam, fluoro-protein foam and aqueous film forming foam (AFFF) as fire extinguishants with induction rates of 2,3,4 and 5 litres $/ \mathrm{m}^{2} / \mathrm{min}$, brings about $90 \%$ control and completely extinguishes the fires within a minute's time. The DFIT has significant fire extinguishing effectiveness at the optimum induction rate of 3 litres $/ \mathrm{m}^{2} / \mathrm{min}$. An Indian patent for the technique has been already filed vide application no. 1105/DEL/89.
\end{abstract}

\section{KEYWORDS}

Foam technique, Combustion zone, Foam extinguishants, Size of fire, Extinguishment.

\section{INTRODUCTION}

Theories of fire suppression and extinction involve two essential variables : an extinguishing agent and a system or procedure for its application. Extinction of a hydrocarbon fire is a phenomenon of challenging magnitude and experience. The work by Ahonen [1] determines the extinguishing capability of mechanical fire extinguishing foams by performing extinguishing tests on burning trays containing motor petrol. Breen [2] carried out suppression of class A fuel fires in simulated ship cargo holds using high-expansion foam and water deluge systems. DiMaio [3] conducted experiments on evaluation of aspirating vs. nonaspirating nozzles for making fire fighting foams. 
The work of McDaniel [4] has shown the fire extinguishing effectiveness of synthetic surfactant foam and of Tuve [5] on mechanical foams for fuel fire extinguishment. Welker et al. [6] carried out work on effectiveness of fire control agents on chemical fires, highlighting future tests that should establish scaling parameters to allow use of smaller surface areas for the comparative effectiveness tests. The recent work by Sharma et al. $[7,8]$ on extinction of liquid hydrocarbon fires by a particulate mineral experimentally demonstrates the fire extinguishing effectiveness of the exfoliated vermiculite as a particulate fire extinguishing agent for flammable liquid tank fires. There are two popular foam systems [9] for the extinguishment of oil storage tank fires : one is top side application system and the other is subsurface foam injection system. The subsurface foam injection system is a fire extinguishing system which applies the foam from the underside of the fire by injecting it under the pressure of the head of the fuel in the tank, using the high back pressure foam maker. The problems[9] inherent with the top side application are sometimes difficult to combat, which may consist of explosion or fire damage to the foam makers or tankside piping; forceful upward fire drafted air currents that prevent the falling foam from reaching the burning surface; hazards to workers attempting to erect portable foam distribution devices near the burning tank; or inability of foam applied from the periphery of a large tank (greater than about $61 \mathrm{~m}$ in diameter) to flow and form a complete centre seal during fire attack. The problem[9,10] associated with subsurface / semi-subsurface applications is that the foam bubbles of the foam being injected under the pressure of the head of the fuel in the tank, carry along with them a part of the flammable liquid onto its bubble surface, so called the phenomenon of fuel pick-up, resulting ultimately into the partial break-down/ disintegration of foam bubbles during or after passage up through the fuel; thus jeopardising the purpose for which it has been installed. Subsurface foam injection systems are not generally recommended[9] for open top or covered floating roof tanks because of the possibility of tilted or sunken roofs resulting in improper foam distribution.

The obvious solution to these problems is to carry the foam in a piping work through the contents of the tank, causing it to come up without any considerable loss of head and extinguishing properties and discharging it uniformly and gently onto the burning liquid fuel surface, thus enhancing the overall efficiency and effectiveness of the system in combating the fire in its early stages of growth and development. This concept has been evolved in this present investigation as to feature out the significance of the direct injection of foam into the combustion zone of fire as a novel technique for the fixed foam fire protection of the open top and/or the covered floatingroof and the cone-rooffuel storage tanks. In case of the cone-roof fuel storage tank, the direct foam injection technique is very simple to be installed on the like pattern of any other existing top side application foam systems erection code with improved modifications and considerations to the internal system structural stability. But for the open top or covered floating roof tank, it has to come up through the floating-roof in the form of vertical pipe-work on the similar pattern as that of the guide $\operatorname{rod}(\mathrm{s})$, being provided to the floating-roof.

Since free-burning pools of liquid fuels exhibit the basic features of many fires of practical interest and also, it is difficult and expensive to perform fire experiments simulating natural and practical full scale conditions, it has been, therefore, planned in this present investigation to perform experiments at a laboratory scale, taking into consideration the free burning pool of size $: 4.0 \mathrm{~m}$ $x 2.5 \mathrm{~m}$, using a technique of direct injection of foam into the combustion zone of fire at the initial stage of flame growth and development. 
The following sections describe the experimental arrangement and the experiments carried out using a direct foam injection technique. The results of the experiments are then briefly discussed.

\section{EXPERIMENTAL SYSTEM}

Figure 1 shows a schematic illustration of the experimental arrangement for carrying out the liquid hydrocarbon open-tank fire experiments, using an application technique of direct injection of foam

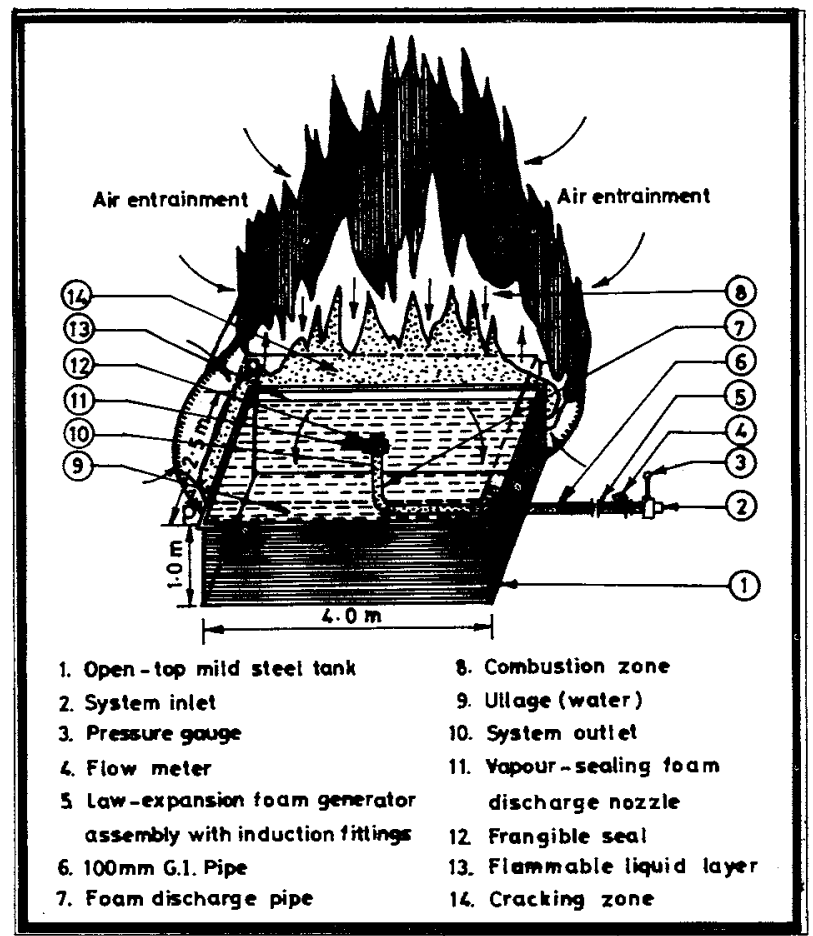

FIGURE 1: Experimental set-up into the combustion zone of fire as a fire extinguishing technique. The experimental system consists of an opentop mild steel tank of size : $4.0 \mathrm{~m} \times 2.5 \mathrm{~m}$ and $1 \mathrm{~m}$ height, filled with water to $80 \%$ of its total volume as an ullage to the flammable liquid layer. A direct foam injection technique is a prototype system which comprises of a 100 $\mathrm{mm}$ pipework being fitted at the bottom of the tank with a low-expansion-foam generator assembly at the inlet, and the vapour-sealing foam discharge nozzle at the outlet. The discharge geometry of the vapour-sealing foam discharge nozzle comprises of an appropriate size and shape discharge ports/holes, being perfectly sealed with an appropriate frangible seal capable of preventing the flammable vapour from entering the foam piping. These seals are designed to burst when foam pressure is applied. The positioning of the outlet of the foam discharge pipe and the vapour-sealing foam discharge nozzle was kept centrally in the tank and its height was vertically fixed, $15-20 \mathrm{~cm}$ above the maximum permissible (in accordance to the prevailing Petroleum Rules/Regulations-worldwide) and safe flammable liquid storage level limit. This leaves a sufficient working space for foam extinguishants as to create a coherent blanket for cutting off the feed of fuel vapour and air to the combustion zone of fire. Foam is produced by mixing a foam concentrate with water at the appropriate concentration, and then aerating and agitating the solution to form the bubble structure. The entry of foam may be provided at several points at the base of the tank, depending upon the size and geometry of the fuel storage tanks. When large tanks are involved, a branched pipe foam distributer 
may be installed on or slightly above the floor of the tank above any expected water level, if any and connected to a central foam injection point outside the tank.

\section{EXPERIMENTS}

The buoyancy-dominated oil storage tank fires were thought to be better tackled if attacked by a stabilised foaming agent with proper application technique. Therefore, all the experiments were planned to be carried out by using such an application technique which could automatically apply a stablized foam extinguishant onto the seat of fire, uniformly and gently, covering the whole of the burning liquid fuel surface area, steadily building up a continuous and floating layer of vapour sealing, air excluding, water bearing and cooling, cohesive and heat resistant blanket of aggregate of air-filled bubbles formed from the aqueous solutions of specially formulated concentrated liquid foaming agents (Some foams such as fluoro-protein foam are thick and viscous and form tough, heat resistant blankets over burning liquid surfaces; other foams such as AFFF are thinner and spread more rapidly). This was thought to be an effective method of carrying out the extinguishing experiments of open-tank liquid hydrocarbon fires by cutting off the supply of fuel vapour to the combustion zone of the fire. All the experiments were carried out in the $4.0 \mathrm{~m} \times 2.5 \mathrm{~m}$ size tank, using in each run, 100 litres of gasoline, kerosene and diesel oil as fuels,

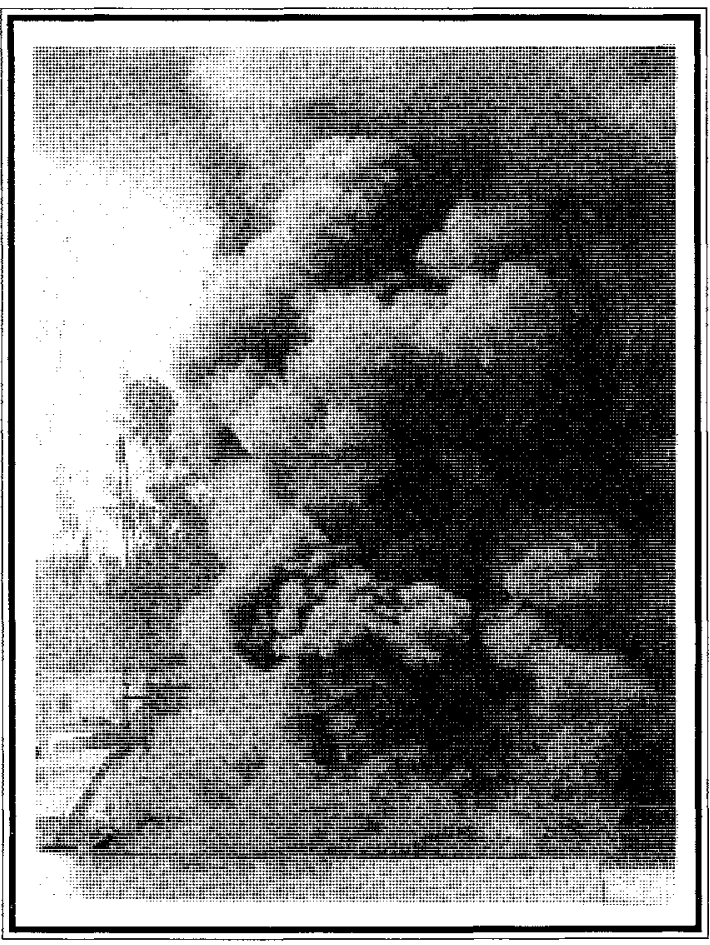

FIGURE 2: Photographic view of the experimental set-up in fire condition being spilled to a depth of $0.01 \dot{m}$ over a confined area of $10 \mathrm{~m}^{2}$ with the water ullage to a depth of $0.79 \mathrm{~m}$. The maximum depth of $0.79 \mathrm{~m}$ was selected on the basis of the consideration that in any flammable liquid storage tank, the maximum permissible volume of flammable liquid to be stored is $80 \%$ of its total storage capacity, which is $0.79 \mathrm{~m}$ for a $1 \mathrm{~m}$ - high experimental tank. This leaves a $0.01 \mathrm{~m}$ working space for conducting the fire extinguishing experiments on flammable liquids for a fuel depth of $0.01 \mathrm{~m}$. Three series of experiments were conducted for three different types of foam extinguishants with minimum, critical and sub-critical induction rates of $2,3,4$ and 5 litres $/ \mathrm{m}^{2} / \mathrm{min}$. so as to evaluate the effectiveness of the direct foam injection technique into the combustion zone of fire whether or not it controls $(90 \%)$ and completely extinguishes the fire in its incipient stages of growth and development. Figure 2 shows the photographic view of the experimental set-up in 
the fire condition. The first series of experiments were conducted with protein foam as an extinguishant; and the second and third series of experiments with fluoro-protein foam and aqueous film forming foam (AFFF) extinguishants having 7.5, 8.5 and 9.0 expansion ratios, respectively. The fire was attempted to be controlled and extinguished in each series of experiments after a preburn time of $45 \mathrm{~s}$, using direct foam injection technique into the combustion zone of fire and for each set of fuel-extinguishant-application rate, the observations were made for the $90 \%$ control time, the extinguishment time, the total application time and the burnback resistance. the $90 \%$ control time was measured with due consideration to the arguments of the fire fighters on "control of fire", usually $90 \%$, since in case of extinguishment, there is no single performance index for fire fighting foams and therefore, it is of great significance to the fire fighters for their morale boosting during tactical fire fighting operation, that after all the fire is under control and at any moment of time, it may be extinguished. The $90 \%$ control time may be defined as the time required to bring about the $90 \%$ coverage over the burning fuel surface area by the foam. The total application time of foam was kept double the extinguishment time so as to give the sufficient period of burnback resistance against any eventuality of fire to reflash as a measure of safety. The burnback resistance may be defined as the resistance in time unit offered by the foam against the fire to reflash after its complete extinction, being resulted by the application of the foam onto the burning fuel surface.

\section{RESULTS AND DISCUSSION}

The criterion for making comparisons between different oil pool fires is related to the heat transfer mechanism controlling the vapourisation of fuel at the burning pool surface. When comparing features of fires which may be affected by the heat transfer mode, the fires should be greater than one metre in diameter to duplicate this feature of large fires[11]. Thus, higher buoyancy forces prevail in the flame zone in the large fires in contrast to smaller luminuous flames. This effect is difficult, if not impossible, to reproduce in smaller combustion experiments. Therefore, it has been planned to conduct experimental studies on the extinguishment of $10 \mathrm{~m}^{2}$ size large scale liquid hydrocarbon fires in a $4.0 \mathrm{~m} \times 2.5 \mathrm{~m}$ size and $1 \mathrm{~m}$ high experimental tank, as shown in Figure 1, selecting gasoline, kerosene and diesel oil as fuels.

The fire extinguishant application technique is one of the important primary characteristics of fire extinction. The method adopted in this investigation with a foam extinguishant is the physical isolation of the reducing agent (fuel) in the pqrs plane of the fuel from the fuel vapour-oxidizing agent (air), as illustrated in Figure 1. This plane consists of a gaseous mass of flammable mixer, forming the cracking zone for the high-temperature pyrolysis that sustains the diffusion flame of such fires. This zone is critical because if it is physically replaced or manipulated, the fire will be extinguished. The physical isolation of the fuel in the pqrs plane was accomplised automatically by direct injection of foam into the combustion zone of fire. This application is initiated by the fire detection system coupled with actuation system, which presses into operation the pumping system which takes care of in-line induction and generation of foam in the foam generator assembly and further, application of foam ont the burning liquid fuel surface through the foam discharge nozzle. As the foam starts spreading gently and uniformly onto the burning liquid fuel surface, it occupies the space of the fuel vapour-oxidising agent(air) plane, thus isolating the fuel surface by covering it physically with a continuous, floating, water-bearing, cooling, vapour-sealing, air-excluding, cohesive, viscous and heat resistant blanket of aggregate of air-filled watery foam bubbles. For 
extinction, physical covering of the foam extinguishant is critically necessary as to create a cohesive blanketing effect so as to cut off the feed of the fuel vapour and air to the combustion zone of the fire, and for cohesive blanketing effect of the foam extinguishant, its gentle and uniform application is critically necessary and economically important as well

The preburn time of $45 \mathrm{~s}$ was given as to allow the fire to grow and develop fully since it was experimentally [8] observed that $45 \mathrm{~s}$ time-duration may be critically necessary and sufficient for the growth and development of these liquid hydrocarbon fires.

The critical conditions for the foam technique were studied experimentally at the minimum, critical and sub-critical foam induction rates of protein foam, fluoro-protein foam and aqueous film forming foam (AFFF) extinguishants, and observations were made in terms of the efficiency parameters : the $90 \%$ control time, the extinguishment time, the total application time and the burnback resistance, keeping other parameters such as : preburn time, depth of flammable liquid layer, depth of water (ullage), size of fire, foam concentration, input pressure and water application rate, constant at $45 \mathrm{~s}, 0.01 \mathrm{~m}, 0.79 \mathrm{~m}, 10 \mathrm{~m}^{2}, 3 \%, 700 \mathrm{kN} / \mathrm{m}^{2}$ and $0.00375 \mathrm{~m}^{3} / \mathrm{s}$, respectively. These parameters were kept constant as to take more severe experimental conditions at one time for different induction rates of foam extinguishants as if simulating the natural fire condition, as shown in Figure 2, in the event that, the fully filled flammable liquid storage tank has been engulfed in the fire, and the fire has been fully grown and developed, but it is still in the

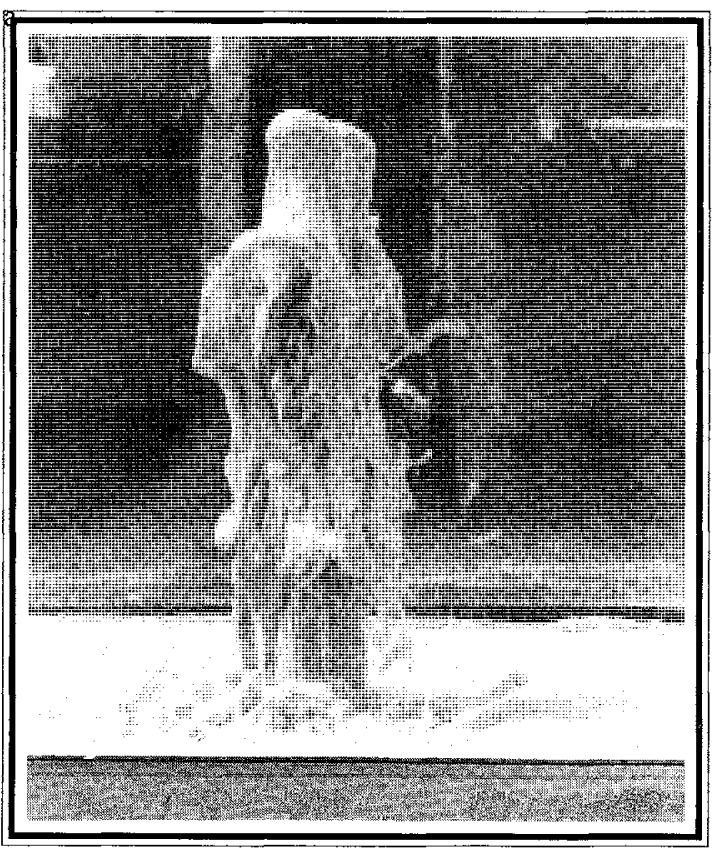

FIGURE 3: Photographic view of the experimental set-up in the extinction condition incipient stages from the point of initiation and now, it is to be brought under control and completely extinguished effectively and efficiently in the early stages of its growth and development. The complete extinction condition of the fire is photographically depicted in Figure 3 . The rate of application of foaming solution per unit area determines the times required to control and extinguish the fire. The minimum foam concentration induction rate is the application rate which is sufficient and enough to extinguish the fire completely. The critical foam concentration induction rate is the minimum application rate which is just sufficient to control and extinguish the fire completely. The sub-critical foam concentration induction rate is the critical application rate below which the fire may be or may not be controlled or extinguished. The phenomenon of partial extinction of fire may usually take place at and below 
the sub-critical induction rates. Where the phenomenon of momentarily stable residual flames near or at the tank wall side takes place, it has been defined as the partial extinction of fire, as photographically depicted in Figure 4.

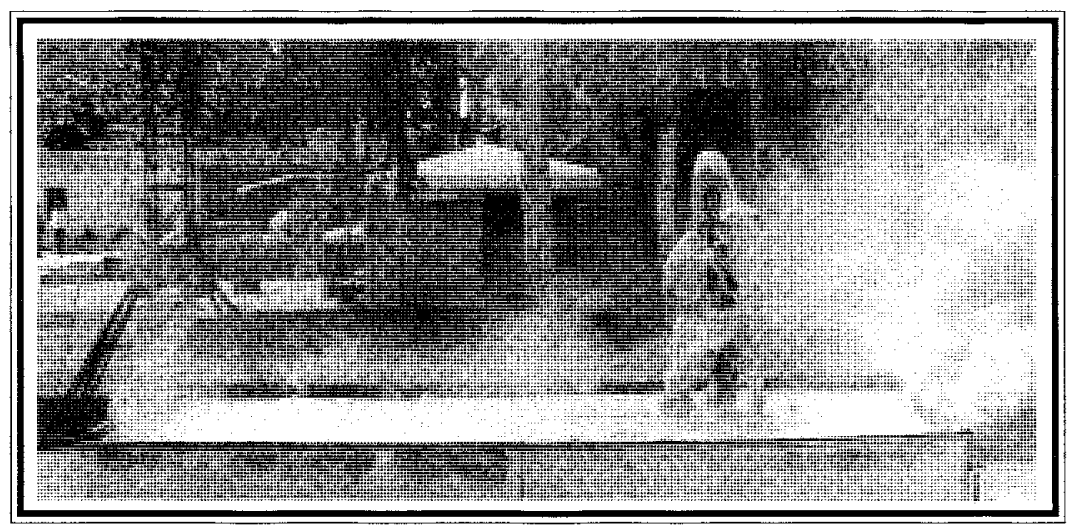

FIGURE 4: Photographic view of the partial extinction of the fire

Keeping in view the importance of the extinguishant application technique in the extinguishment of the fires, in this present investigation, the foam concentration induction rates of $2,3,4$ and 5 litres $/ \mathrm{m}^{2} / \mathrm{min}$ were selected on the basis of series of several experimental runs on protein foam, fluoro-protein foam and AFFF extinguishants, and out of these several experimental runs, the optimum foam concentration induction rate has been inferred to as the most economical induction rate for this direct foam injection technique. The most economical rate may be defined as the optimum application rate (usually it is some 3 to 5 times higher the critical rate[12] or even less depending upon effectiveness and efficacy of the foam application technique employed), at which the fire is extinguished completely with the least quantity of foaming solution. For protein foam extinguishant, 5 litres $/ \mathrm{m}^{2} / \mathrm{min}$ has been found to be critical induction rate and 4 litres $/ \mathrm{m}^{2} / \mathrm{min}$ as the sub-critical foam concentration induction rate, whereas in case of fluoro-protein foam and AFFF extinguishants, 5 and 4 litres $/ \mathrm{m}^{2} / \mathrm{min}$ and 4 and 3 litres $/ \mathrm{m}^{2} / \mathrm{min}$ were observed to be the minimum and critical induction rates, and 3 and 2 litres $/ \mathrm{m}^{2} / \mathrm{min}$ as sub-critical induction rates, respectively. At 1 litre $/ \mathrm{m}^{2} / \mathrm{min}$ foam concentration induction rate, the phenomenon of partial extinction of fire occurs in case of all the three foam extinguishants. Whereas at 6 litres $/ \mathrm{m}^{2} / \mathrm{min}$ induction rate, which has been also found to be the minimum foam concentration induction rate for protein foam extinguishant, it has been observed that in case of fluoro-protein foam and AFFF extinguishants, it works out to be maximum as regards to the relative decrease in the extinguishment time by I or 2 seconds. This was the reason that the induction rates of $2,3,4$ and 5 litres $/ \mathrm{m}^{2} / \mathrm{min}$ were considered in this present investigation. The gentle and uniform application of the foam extinguishants with these induction rates has been greatly achieved by the direct injection of foam into the combustion zone of fire, as illustrated in Figure 5(x). The results of the experiments carried out on $10 \mathrm{~m}^{2}$ size gasoline, kerosene and diesel oil fires for $2,3,4$ and 5 litres/ $\mathrm{m}^{2} / \mathrm{min}$ foam concentration induction rates were summarized in Tables 1,2 and 3 for protein foam, fluoro-protein foam and AFFF extinguishants, respectively. 


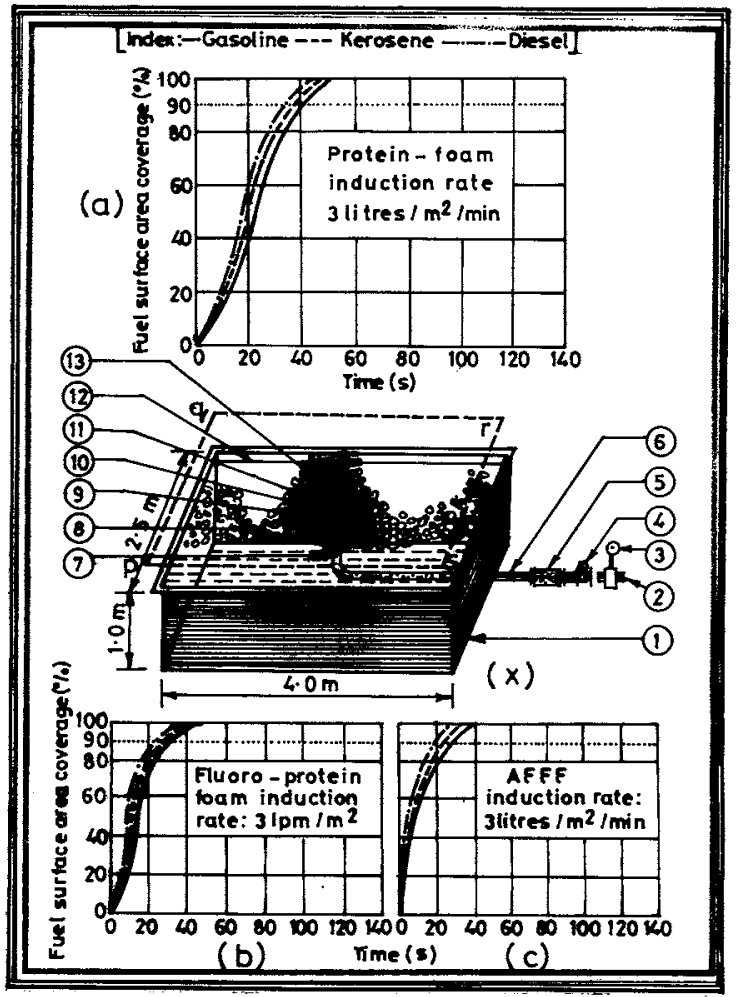

Table 1 shows that for the critical and sub-critical rates of 5 and 4 litres $/ \mathrm{m}^{2} /$ min and even below sub-critical rates that is up to 2 litres $/ \mathrm{m}^{2} / \mathrm{min}$ of protein foam extinguishant, the fire was most effectively and efficiently brought under $90 \%$ control and extinguished completely within a maximum of 1 minute's time in case of gasoline fire and in 57 and 54 seconds in case of kerosene and diesel oil fires at far below sub-critical rate of 2 litres $/ \mathrm{m}^{2} /$ min, using the direct foam injection technique into the combustion zone of fire. The most economical rate for the direct foam injection technique (DFIT) in case of protein foam extinguishant was found to be 3 litres/ $\mathrm{m}^{2} / \mathrm{min}$ with $90 \%$ control and extinguishment times of 39 and $51 \mathrm{~s}, 36$ and 50 s, 33 and 48 s for gasoline, kerosene and diesel oil fires, respectively.

The Figure 5(a) shows the variation of the fuel surface area coverage versus time. The significance of the figure lies in the determination of the

FIGURE 5: Graphical representation for fuel surface area coverage (\%) vs. time (s) for (a) Protein foam, (b) Fluoro-protein foam, (c) AFFF extinguishants and (x) the foam movement and distribution across the burning fuel surface.

TABLE 1 : Experimental data for protein foam extinguishant using direct foam injection technique

\begin{tabular}{|llllll|}
\hline Fuel & $\begin{array}{l}\text { Induction } \\
\text { rate }\end{array}$ & $\begin{array}{l}90 \% \\
\text { control } \\
\text { time } \\
(\mathrm{min} \cdot \mathrm{sec})\end{array}$ & $\begin{array}{l}\text { Extinguish- } \\
\text { ment time } \\
(\mathrm{min} / \mathrm{m}) \mathrm{m})\end{array}$ & $\begin{array}{l}\text { Total } \\
\text { application } \\
\text { time } \\
(\mathrm{min}: \mathrm{sec})\end{array}$ & $\begin{array}{l}\text { Burn } \\
\text { back } \\
\text { resistance } \\
(\mathrm{min})\end{array}$ \\
\hline Gasoline & 2.0 & 0.50 & $1: 00$ & $2: 00$ & 18.0 \\
Gasoline & 3.0 & 0.39 & $0: 51$ & $1: 42$ & 18.0 \\
Gasoline & 4.0 & 0.33 & $0: 46$ & $1: 32$ & 18.0 \\
Gasoline & 5.0 & 0.28 & $0: 40$ & $1: 20$ & 18.0 \\
Kerosene & 2.0 & 0.44 & $0: 57$ & $1: 54$ & 20.0 \\
Kerosene & 3.0 & 0.36 & $0: 50$ & $1: 40$ & 20.0 \\
Kerosene & 4.0 & 0.28 & $0: 44$ & $1: 28$ & 20.0 \\
Kerosene & 5.0 & 0.22 & $0: 38$ & $1: 16$ & 20.0 \\
Diesel & 2.0 & 0.42 & $0: 55$ & $1: 48$ & 20.0 \\
Diesel & 3.0 & 0.33 & $0: 48$ & $1: 34$ & 20.0 \\
Diesel & 4.0 & 0.26 & $0: 42$ & $1: 24$ & 20.0 \\
Diesel & 5.0 & 0.20 & $0: 37$ & $1: 14$ & 20.0 \\
\hline
\end{tabular}


trend of the "burning fuel surface area coverage" by the protein foam at the most economical induction rate during the course of time, right from the initiation of the foam application till the complete extinction of the fire. The trend of the percentage burning fuel surface area coverage by the protein foam at the most economical induction rate of $3 \mathrm{litres} / \mathrm{m}^{2} / \mathrm{min}$. has been found to be exponentially rising smoothly till the complete extinction of the fire in case of all the three fuel fires :gasoline, kerosene and diesel.

TABLE 2 : Experimental data for fluoro-protein foam extinguishant using direct foam injection technique

\begin{tabular}{|c|c|c|c|c|c|}
\hline Fuel & $\begin{array}{l}\text { Induction } \\
\text { rate } \\
\left(\mathrm{lpm} / \mathrm{m}^{2}\right)\end{array}$ & $\begin{array}{l}90 \% \\
\text { control } \\
\text { time } \\
\text { (min }: \mathrm{sec} \text { ) }\end{array}$ & $\begin{array}{l}\text { Extinguish- } \\
\text { ment time } \\
\text { (min:sec) }\end{array}$ & $\begin{array}{l}\text { Total } \\
\text { application } \\
\text { time } \\
\text { (min:sec) }\end{array}$ & $\begin{array}{l}\text { Burn } \\
\text { back } \\
\text { resistance } \\
\text { (min) }\end{array}$ \\
\hline Gasoline & 2.0 & 0.35 & $0: 52$ & $1: 44$ & 22.0 \\
\hline Gasoline & 3.0 & 0.28 & $0: 43$ & $1: 32$ & 22.0 \\
\hline Gasoline & 4.0 & 0.23 & $0: 40$ & $1: 22$ & 22.0 \\
\hline Gasoline & 5.0 & 0.20 & $0: 36$ & $1: 12$ & 22.0 \\
\hline Kerosene & 2.0 & 0.32 & $0: 47$ & $1: 34$ & 25.0 \\
\hline Kerosene & 3.0 & 0.26 & $0: 42$ & $1: 24$ & 25.0 \\
\hline Kerosene & 4.0 & 0.22 & $0: 38$ & $1: 16$ & 25.0 \\
\hline Kerosene & 5.0 & 0.19 & $0: 35$ & $1: 10$ & 25.0 \\
\hline Diesel & 2.0 & 0.30 & $0: 45$ & $1: 30$ & 25.0 \\
\hline Diesel & 3.0 & 0.25 & $0: 41$ & $1: 20$ & 25.0 \\
\hline Diesel & 4.0 & 0.21 & $0: 36$ & $1: 12$ & 25.0 \\
\hline Diesel & 5.0 & 0.18 & $0: 34$ & $1: 08$ & 25.0 \\
\hline
\end{tabular}

Table 2 shows that for the minimum, critical and sub-critical rates of 5,4 and 3 litres $/ \mathrm{m}^{2} / \mathrm{min}$ and even below the sub-critical rate that is at $2 \mathrm{litres} / \mathrm{m}^{2} / \mathrm{min}$ of fluoro-protein foam extinguishant, the fire was most effectively and efficiently brought under $90 \%$ control and extinguished completely within a maximum of 52 seconds time in case of gasoline fire and in 47 and 45 seconds in case of kerosene and diesel oil fires at far sub-critical rate of $2 \mathrm{litres} / \mathrm{m}^{2} / \mathrm{min}$, using the direct foam injection technique into the combustion zone of fire. The most economical rate for the direct foam injection technique (DFIT) in case of fluoro-protein foam extinguishant was interestingly observed to be 3 litres $/ \mathrm{m}^{2} / \mathrm{min}$ with $90 \%$ control and extinguishment times of 28 and $43 \mathrm{~s}, 26$ and $42 \mathrm{~s}, 25$ and $41 \mathrm{~s}$ for gasoline, kerosene and diesel oil fires, respectively.

The Figure 5(b) shows the variation of the fuel surface area coverageversus time. The significance of the figure lies in the determination of the trend of the "burning fuel surface area coverage" by the fluoro-protein foam at the most economical induction rate during the course of time, right from the initiation of the foam application till the complete extinction of the fire. The trend of the percentage burning fuel surface area coverage by the fluoro-protein foam at the most economical induction rate of $3 \mathrm{litres} / \mathrm{m}^{2} / \mathrm{min}$. has been found to be exponentially rising smoothly till the complete extinction of the fire in case of all the three fuel fires : gasoline, kerosene and diesel. 
TABLE 3 : Experimental data for AFFF extinguishant using direct foam injection technique

\begin{tabular}{|llllll|}
\hline Fuel & $\begin{array}{l}\text { Induction } \\
\text { rate }\end{array}$ & $\begin{array}{l}90 \% \\
\text { control } \\
\text { time } \\
(\mathrm{min}: \mathrm{sec})\end{array}$ & $\begin{array}{l}\text { Extinguish- } \\
\text { ment time } \\
\left(\mathrm{min} / \mathrm{m} \mathrm{m}^{2}\right)\end{array}$ & $\begin{array}{l}\text { Total }) \\
\text { application } \\
\text { time } \\
(\mathrm{min}: \mathrm{sec})\end{array}$ & $\begin{array}{l}\text { Burn } \\
\text { back } \\
\text { resistance } \\
(\mathrm{min})\end{array}$ \\
\hline Gasoline & 2.0 & 0.30 & $0: 37$ & $1: 28$ & 09.0 \\
Gasoline & 3.0 & 0.26 & $0: 33$ & $1: 15$ & 09.0 \\
Gasoline & 4.0 & 0.22 & $0: 31$ & $1: 06$ & 09.0 \\
Gasoline & 5.0 & 0.18 & $0: 29$ & $1: 00$ & 09.0 \\
Kerosene & 2.0 & 0.27 & $0: 35$ & $1: 10$ & 10.0 \\
Kerosene & 3.0 & 0.20 & $0: 32$ & $1: 05$ & 10.0 \\
Kerosene & 4.0 & 0.17 & $0: 30$ & $1: 00$ & 10.0 \\
Kerosene & 5.0 & 0.16 & 0.28 & $0: 56$ & 10.0 \\
Diesel & 2.0 & 0.25 & $0: 34$ & $1: 08$ & 10.0 \\
Diesel & 3.0 & 0.20 & $0: 31$ & $1: 00$ & 10.0 \\
Diesel & 4.0 & 0.17 & $0: 29$ & $0: 58$ & 10.0 \\
Diesel & 5.0 & 0.15 & $0: 27$ & $0: 54$ & 10.0 \\
\hline
\end{tabular}

Table 3 shows that for the minimum, critical and sub-critical rates of 4,3 and 2 litres $/ \mathrm{m}^{2} / \mathrm{min}$ of AFFF extinguishant, the fire was most effectively and efficiently brought under $90 \%$ control and extinguished completely within a maximum of 37 seconds time in case of gasoline fire and in 35 and 34 seconds in case of kerosene and diesel oil fires at sub-critical rate of 2 litres $/ \mathrm{m}^{2} / \mathrm{min}$, using the direct foam injection technique into the combustion of fire. The most economical rate for the direct foam injection technique (DFIT) in case of AFFF extinguishant was again inferred to be 3 litres $/ \mathrm{m}^{2} / \mathrm{min}$ with $90 \%$ control and extinguishment times of 26 and $33 \mathrm{~s}, 20$ and $32 \mathrm{~s}, 20$ and $31 \mathrm{~s}$ for gasoline, kerosene and diesel oil fires, respectively.

The Figure 5(c) shows the variation of the fuel surface area coverage versus time. The significance of the figure lies in the determination of the trend of the "burning fuel surface area coverage" by the AFFF at the most economical induction rate during the course of time, right from the initiation of the foam application till the complete extinction of the fire. The trend of the percentage burning fuel surface area coverage by the AFFF at the most economical induction rate of 3 litres $/ \mathrm{m}^{2} / \mathrm{min}$. has been found to be exponentially rising smoothly till the complete extinction of the fire in case of all the three fuel fires : gasoline, kerosene and diesel.

From the above discussion, it may be of great significance to infer that inspite of the qualitative difference in the foam extinguishants(AFFF : fluoro-protein foam : protein foam), the most economical foam concentration induction rate for the direct foam injection technique works out to be 3 litres $/ \mathrm{m}^{2} / \mathrm{min}$ for protein foam, fluoro-protein foam and the AFFF extinguishants in case of $10 \mathrm{~m}^{2}$ size gasoline, kerosene and diesel oil fires, being completely extinguished at 51,50 and $48 s ; 43,42$ and $41 s$ and 33,32 and 31 s, respectively. It has been also found that in all the three series of experiments, the fire has been found to be completely extinguished within, to the maximum of one minute's time, irrespective of the critical, sub-critical and even below the subcritical rates of induction of foam concentration into the application system. 


\section{CONCLUDING REMARKS}

An experimental study with a direct injection of foam into the combustion zone of fire has experimentally demonstrated the suitability of the direct foam injection technique (DFIT) as an efficient and effective fire extinguishing technique for the extinguishment of the flammable liquid storage tank fires. The important conclusions of the study are as follows : The fire extinguishing effectiveness of the direct foam injection technique is optimum at $3 \mathrm{litres} / \mathrm{m}^{2} / \mathrm{min}$ foam concentration induction rate for the $10 \mathrm{~m}^{2}$ size fully filled open-top flammable liquid storage tank fire. For $4.0 \times 2.5 \mathrm{~m}$ size gasoline, kerosene and diesel oil fires, the direct foam injection technique brings about $90 \%$ control and completely extinguishes the fires within a minute's time.

In case of extinguishment, there is no single performance index for a fire fighting foam. Some fire fighters would argue that a "Control of Fire", usually $90 \%$, is of significance. It may be applied equally to a partially blanketed fire where only exposed fuel as that of oil storage tank is burning, or to a fully blanketed oil pool fire where the contaminated foam blanket is burning. Progressive study of these fires in two dimensional space will obviously be quite different.

\section{ACKNOWLEDGEMENTS}

The authors are grateful to the Director, Central Building Research Institute, Roorkee for according permission for publication of the paper in the "International Association for Fire Safety Science". The authors are also thankful to Miss Deepti Gupta and Mr. Rajiv Sharma for their untiring efforts in typing the manuscript.

\section{REFERENCES}

1. Ahonen, A., Espoo Research Report 130; Technical Research Centre of Finland, 37 p. October, 1982.

2. Breen, D.E., Factory Mutual Research Corporation, Norwood, MA, FinalReport, FMRC Serial 19242; RC73-T-46; 101 p. May, 1974.

3. DiMaio, L.R., Fire Technology, $20: 1,5-10,1984$.

4. McDaniel, D.E., Coast Guard, Mobile, AL, Final Report, USCG-D-101-74; CGR/DC16/74; 60 p., 1974.

5. Tuve, R.L., Fire Extinguishment Research and Engineering Proceedings of the Sympo sium; Port Hueneme, CA, 254-267 pp, November 16-18, 1954.

6. Welker, J.R., Applied Technology Corporation, Norman, OK, Final Report, CG-D-50$80 ; 147$ p. June, 1980.

7. Sharma, T.P., Badami, G.N., Lal, B.B. and Singh, Jagbir, Fire Safety Science-Proceedings of the Second International Symposium, held in July 1988, Tokyo, Japan, 1989.

8. Sharma, T.P., Chimote, R.S., Lal, B.B. and Singh, Jagbir, Combustion and Flame 89 2, 229-234, 1992.

9. Lockwood, N.R., Fire Protection Handbook, Sixteenth Edition, pp. 19.32 - 19.48, National Fire Protection Association, Quincy, Massachusetts, 1986.

10. Mahley, Horace S., "Fight Tank Fires Subsurface", in Hydrocarbon Processing, pp. 142$146,1975$. 
11. Mudan, Krishna S. and Croce, Paul A., "Fire Hazard Calculations for Large Open Hydrocarbon Fires", in The SFPE Handbook of Fire Protection Engineering, First Edition, pp. 2-45-2-87, Society of Fire Protection Engineers, Boston and National Fire Protection Association, Quincy, Massachusetts, 1988.

12. Nash, P., "The Essentials of Foam, Dry Powder and Gaseous Extinguishing Systems", Fire Prevention (117) 20-25; (118) 21-24, 1977. 